\title{
Performance analysis of PV panel under varying surface temperature
}

\author{
Tripathi Abhishek Kumar ${ }^{1 *}$, Murthy Ch. S. $\mathrm{N}^{1}$ and Aruna Mangalpady ${ }^{1}$ \\ ${ }^{1}$ Department of Mining Engineering, National Institute of Technology Karnataka, Surathkal, India
}

\begin{abstract}
The surface temperature of PV panel has an adverse impact on its performance. The several electrical parameters of $\mathrm{PV}$ panel, such as open circuit voltage, short circuit current, power output and fill factor depends on the surface temperature of PV panel. In the present study, an experimental work was carried out to investigate the influence of PV panel surface temperature on its electrical parameters. The results obtained from this experimental study show a significant reduction in the performance of PV panel with an increase in panel surface temperature. A $5 \mathrm{~W}$ PV panel experienced a $0.4 \%$ decrease in open circuit voltage for every $1^{\circ} \mathrm{C}$ increase in panel surface temperature. Similarly, there was $0.6 \%$ and $0.32 \%$ decrease in maximum power output and in fill factor, respectively, for every $1^{\circ} \mathrm{C}$ increase in panel surface temperature. On the other hand, the short circuit current increases with the increase in surface temperature at the rate of $0.09 \% /{ }^{\circ} \mathrm{C}$.
\end{abstract}

Keywords: Surface temperature, open circuit voltage, short circuit current, maximum power output and fill factor.

\section{Introduction}

The use of energy plays a very vital role in one's life. Thus, it's supply and generation should be secure and sustainable. At the same time, it should be environmentally friendly, socially and economically acceptable. The present scenario of energy generations is neither secure nor sustainable and depends on fossil fuels, nuclear and renewable energy sources. Among these, the renewable energy could be considered as a source of secure and sustainable energy source [1]. There are different types of renewable energy sources, such as hydro, geothermal, biomass, wind and solar. Among all available renewable energy sources, solar energy experienced a rapid growth and popularity in the last one decade. Therefore, solar energy is the most promising and vital energy source to produce electricity in a present scenario [2-4].

In solar energy, photovoltaic (PV) panel is a device that converts sun radiation (solar energy) into electrical energy with the help of photovoltaic effect [5]. Photovoltaic effect is a process in which PV panel generates electric power, when it is exposed to sunlight. Sun light consists of the bundle photons, which are simply absorbed by a PV panel and when a suitable wavelength of photon incident on the panel surface, the energy of the photon is transferred to the electron of the PV material. This causes the electron to move towards a

\footnotetext{
*Corresponding author: abhinitrk112@gmail.com
} 
higher energy state (i.e. conduction band) from a lower energy state (i.e. valence band). This movement of electron is the main cause of generation of an electric current in the PV device [6-8].

The performance of PV panel is highly depended on the environmental parameters, such as solar radiation, wind speed, humidity, dust and atmospheric temperature. The panel surface temperature is a key environmental parameters that influence the performance of PV panel by changing its electrical parameters, such as open circuit voltage (VOC), short circuit current (ISC), maximum power output (PM) and fill factor (FF) [9-10].

In general, PV panels are made of silicon semiconductor material and like all semiconductor material, PV panels are also temperature sensitive. Hence, temperature of PV panel is an important environmental parameter, which affects its performance. The panel surface temperature depends on the encapsulating material, solar radiation, atmospheric temperature, humidity and wind speed [11]. As the temperature of PV panel increases its VOC, PM and FF decreases. Moreover, the ISC of PV panel experiences a very small increments with the rise in its surface temperature. As a result of this, the overall performance of PV panel reduces due to increase in its surface temperature [12]. The rise in panel temperature for c-Si PV panel decreases its VOC at the rate of $-0.45 \% / \mathrm{K}$ [13]. Similarly, the decrease in power output and fill factor of the PV panel to increase in panel surface temperature are at the rate of $-0.65 \% / \mathrm{K}$ and $-0.2 \% / \mathrm{K}$, respectively [14]. A study has shown that the $9 \%$ increments in panel efficiency due to $20 \%$ reduction in the panel surface temperature [15]. Similarly, one more study reported that with the $22^{\circ} \mathrm{C}$ reduction in the panel surface temperature, its power output experienced a gain of $10.3 \%$ [16]. The available literature shows that the surface temperature of PV panel is a vital parameter that affect its performance. Therefore, in this paper, an attempt was made to understand the influence of surface temperature on PV panel performance.

\section{Experimental set-up and methodology}

A 5W polycrystalline PV panel was used to carry out the present investigation. The detail technical specifications of PV panel considered are given in Table 1. The PV panel was mounted on the flat frame with zero inclination and subjected to a constant solar radiation of $1182 \mathrm{~W} / \mathrm{m}^{2}$. This range of solar radiation was generated by using a set of solar simulators and measured by TM-207 solar power meter. The experimental setup used in this study is presented in Figure 1. The PV panel was connected to a variable rheostat of $320 \Omega$ rating through the ammeter (connected in series) and a voltmeter (connected in parallel). A Digital Multimeter Fluke 178+ and DT830B were used as a voltmeter and ammeter in the circuit, which is given in Figure 2. To increase the surface temperature of PV panel a set of infrared dryer bulbs were used and a digital pyrometer was also used to measure the panel temperature of PV panel. The panel temperature was increased from $35^{\circ} \mathrm{C}$ to $65^{\circ} \mathrm{C}$ and the readings of electrical parameters (i.e. current and voltage) were taken at every increase of $10^{\circ} \mathrm{C}$ of panel surface temperature. Based on the obtained reading the other electrical parameters of $\mathrm{PV}$ panel, such as power output and fill factor were calculated. The equation used for calculating the fill factor (FF) of PV panel is given in equation 1.

$\mathrm{FF}=\frac{V_{m} \times I_{m}}{V_{O C} \times I_{S C}}$

where,

$$
\begin{aligned}
& \mathrm{V}_{\mathrm{OC}}=\text { open circuit voltage }(\text { volt }) \\
& \mathrm{I}_{\mathrm{SC}}=\text { Short circuit current }(\mathrm{amp})
\end{aligned}
$$




$$
\begin{aligned}
& \mathrm{I}_{\mathrm{m}}=\text { Maximum current (amp) } \\
& \mathrm{V}_{\mathrm{m}}=\text { maximum voltage (volt) }
\end{aligned}
$$

Table 1. Technical Specification of 5W PV panel.

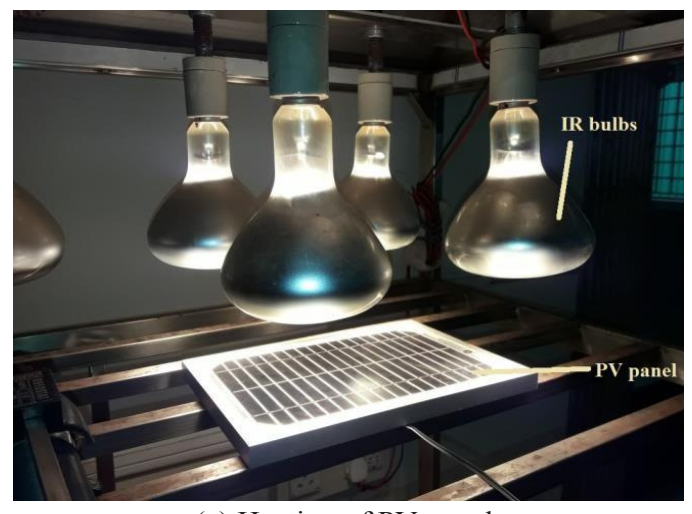

(a) Heating of PV panel

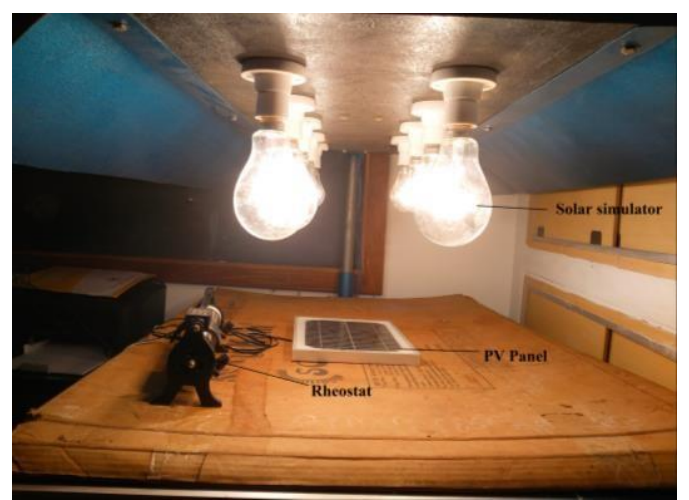

(b) Electric measurement of PV panel

Fig. 1. Experimental set-up.

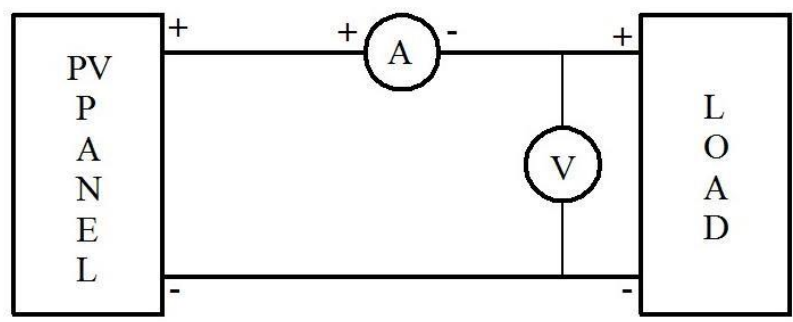

Fig. 2. Circuit diagram. 


\section{Error analyses}

The uncertainty in the measurement may be taken as the possible error of the experimental data. The uncertainty in the measurements may arise from the various experimental errors, such as instrumental error, calibration error, observation error and human error. The uncertainty in the measured values can be explained by the error analysis [17].

Consider, a set of measurements, such as $\mathrm{x}_{1}, \mathrm{x}_{2}, \mathrm{x}_{3} \ldots \ldots . \mathrm{x}_{\mathrm{n}}$, during $\mathrm{N}$ number of trials. Suppose, the possible error $E_{1}, E_{2}, E_{3} \ldots \ldots . . E_{n}$ are introduced in measured results. Then, the possible error in the measured result is given by equation (2). The measured error in the various measurements like, open circuit voltage, maximum power output and fill factor is given in Table 2.

$\mathrm{E}=\left\{\left[\left(\mathrm{x}_{1}-\mathrm{X}_{\mathrm{avg}}\right)^{2}+\left(\mathrm{x}_{2}-\mathrm{X}_{\mathrm{avg}}\right)^{2} \ldots \ldots \ldots \ldots\left(\mathrm{x}_{\mathrm{n}}-\mathrm{X}_{\mathrm{avg}}\right)^{2}\right] / \mathrm{N}\right\}^{1 / 2}$

where,

$\mathrm{E}=$ measured error

$\mathrm{N}=$ number of trials

$\mathrm{x}_{\mathrm{avg}}=$ average values of the $\mathrm{n}$ trials

Table 2. Percentage errors introduced in the measurements

\begin{tabular}{|c|c|c|c|}
\hline $\begin{array}{c}\text { Surface temperature } \\
\text { of the panel }\left({ }^{\circ} \mathrm{C}\right)\end{array}$ & \multicolumn{3}{|l|}{ Percentage error in the measured parameters (\%) } \\
\hline & $\mathrm{V}_{\mathrm{OC}}$ & $\mathrm{P}_{\mathrm{M}}$ & $\mathrm{FF}$ \\
\hline 35 & 4.40 & 4.76 & 2.39 \\
\hline 45 & 3.80 & 8.20 & 2.49 \\
\hline 55 & 2.02 & 5.13 & 2.08 \\
\hline 65 & 1.21 & 4.98 & 0.9 \\
\hline
\end{tabular}

\section{Results and Discussions}

The recorded electrical parameters of PV panel, such as $\mathrm{V}_{\mathrm{OC}}, \mathrm{I}_{\mathrm{SC}}, \mathrm{P}_{\mathrm{M}}$ and FF under varying panel surface temperature are given in Table 3. Based on the recorded electrical parameters the current $(\mathrm{I})$-voltage $(\mathrm{V})$ and power $(\mathrm{P})$-voltage $(\mathrm{V})$ characteristics of $\mathrm{PV}$ panel are plotted at four different surface temperatures (i.e., $35^{\circ} \mathrm{C}, 45^{\circ} \mathrm{C}, 55^{\circ} \mathrm{C}$ and $65^{\circ} \mathrm{C}$ ), which are shown in Figure 3 and Figure 4. As depicted in Figure 3 and Figure 4, surface temperature of PV panel has a significant impact on its I-V and P-V characteristic. The current is almost same in lower voltage range but as the voltage increases a fast reduction in the current is observed for the all four defined surface temperature conditions. As presented in Figure 3 the deformation in the I-V characteristic gets increases with the panel surface temperature. There is a significant reduction in the $\mathrm{V}_{O C}$ of the PV panel with increases in the panel surface temperature, whereas a very small increment in $\mathrm{I}_{\mathrm{SC}}$ is observed. Due to this significant reduction in $\mathrm{V}_{\mathrm{OC}}$ the other electrical parameters (i.e., maximum power output and fill factor) of PV panel also reduces. Therefore, the overall performance of PV panel reduces with the rise in its surface temperature. Moreover, as presented in Figure 4 the maximum power point (MPP) in the PV curve moves towards the lower output voltage with the increase in panel surface temperature. Due to this, the maximum power point tracker algorithm would not be able to operate at a particular maximum power point, which reduces the performance of solar charge controller. Hence, the shifting of MPP in the PV curve directly affects the effective operation of the whole PV systems (i.e., PV panel and charge controller). 
Table 3. Recorded electrical parameters of PV panel.

\begin{tabular}{|c|c|c|c|c|}
\hline $\begin{array}{l}\text { Panel surface } \\
\text { temperature }\left({ }^{\mathbf{}} \mathbf{C}\right)\end{array}$ & VOC $^{\text {(volt) }}$ & ISC (amp) & $\mathbf{P}_{\mathbf{M}}$ (watt) & FF \\
\hline 35 & 9.70 & 0.36 & 2.475 & 0.708 \\
\hline 45 & 9.30 & 0.36 & 2.325 & 0.694 \\
\hline 55 & 8.90 & 0.365 & 2.175 & 0.669 \\
\hline 65 & 8.52 & 0.37 & 2.025 & 0.640 \\
\hline
\end{tabular}

As indicated in Table 3, the reduction in $\mathrm{V}_{\mathrm{OC}}$ is $12.16 \%$ with the increase in panel surface temperature from $35^{\circ} \mathrm{C}$ to $65^{\circ} \mathrm{C}$. Similarly, the reduction in $\mathrm{P}_{\mathrm{M}}$ and $\mathrm{FF}$ are $18.18 \%$ and $9.60 \%$, respectively, due to increase in panel surface temperature. The $\mathrm{P}_{\mathrm{M}}$ and $\mathrm{FF}$ are found to decrease with increase in panel surface temperature due to change in respective current and voltage. The reduction in $\mathrm{P}_{M}$ and $\mathrm{FF}$ with the increase in panel surface temperature are presented in Figure 5 and Figure 6. The maximum power output and fill factor of PV panel decreases linearly with the increase in panel surface temperature. From the Table 2, the temperature coefficient for $\mathrm{V}_{\mathrm{OC}}, \mathrm{I}_{\mathrm{SC}}, \mathrm{P}_{\mathrm{M}}$ and $\mathrm{FF}$ are calculated with the help of Equations (3), (4), (5) and (6). The temperature coefficient for $\mathrm{V}_{\mathrm{OC}}, \mathrm{I}_{\mathrm{SC}}, \mathrm{P}_{\mathrm{M}}$ and $\mathrm{FF}$ are $0.4 \% /{ }^{\circ} \mathrm{C}, 0.09 \% /{ }^{\circ} \mathrm{C}$, $-0.6 \% /{ }^{\circ} \mathrm{C}$ and $-0.32 \% /{ }^{\circ} \mathrm{C}$, respectively.

Temperature Coefficient of $\mathrm{V}_{\mathrm{OC}}=\frac{\Delta V_{O C}}{V_{O C} \times \Delta T} \quad\left(\% /{ }^{\circ} \mathrm{C}\right)$

Temperature Coefficient of $\mathrm{V}_{\mathrm{OC}}=\frac{\Delta I_{S C}}{I_{S C} \times \Delta T} \quad\left(\% / /^{\circ} \mathrm{C}\right)$

Temperature Coefficient of $\mathrm{P}_{\mathrm{M}}=\frac{\Delta P_{M}}{P_{M} \times \Delta T} \quad\left(\% /{ }^{\circ} \mathrm{C}\right)$

Temperature Coefficient of $\mathrm{FF}=\frac{\Delta F F}{\Delta F F \times \Delta T} \quad\left(\% /{ }^{\circ} \mathrm{C}\right)$ where,

$\Delta \mathrm{T}=$ change in panel surface temperature $\left({ }^{\circ} \mathrm{C}\right)$

$\mathrm{V}_{\mathrm{OC}}=$ open circuit voltage of PV panel (volt)

$\Delta \mathrm{V}_{\mathrm{OC}}=$ change in open circuit voltage (volt)

$\mathrm{P}_{\mathrm{M}} \quad$ = maximum power output of PV panel (watt)

$\Delta \mathrm{P}_{\mathrm{M}}=$ change in maximum power output of PV panel (watt)

$\mathrm{FF} \quad=$ fill factor of $\mathrm{PV}$ panel

$\Delta \mathrm{FF}=$ change in fill factor 


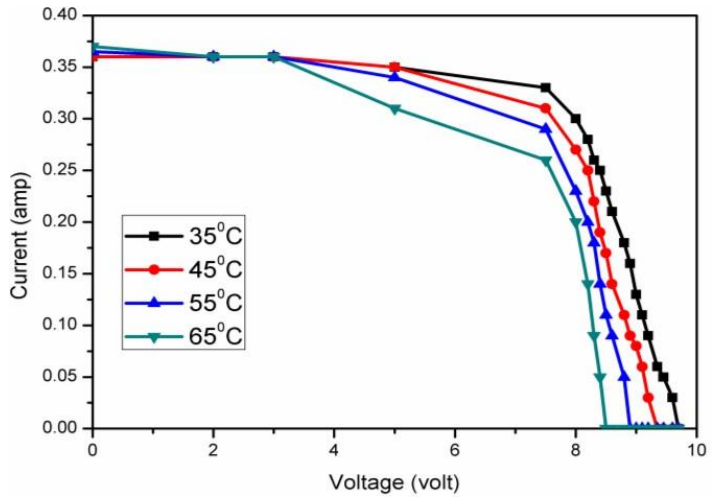

Fig. 3. I-V characteristic of PV panel.

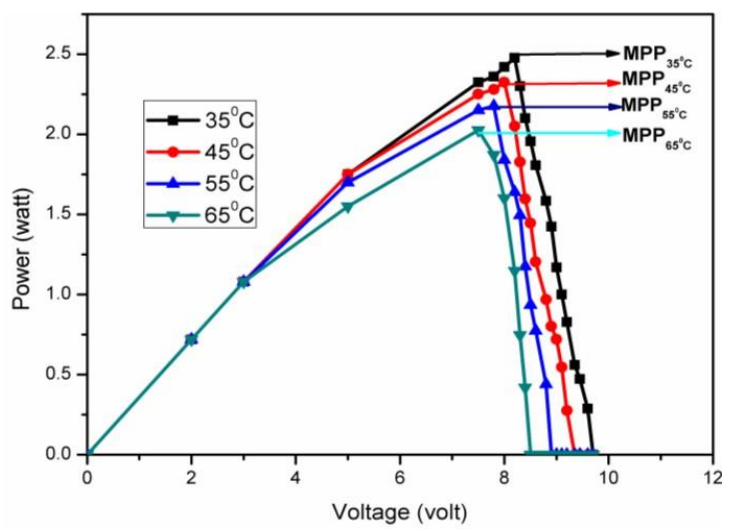

Fig. 4. P-V characteristic of PV panel.

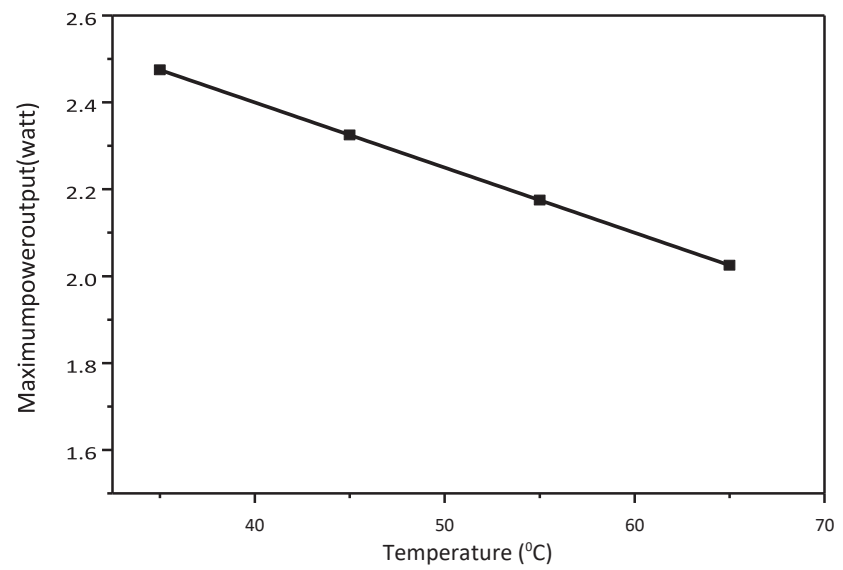

Fig. 5. Variation of maximum power output with panel surface temperature. 


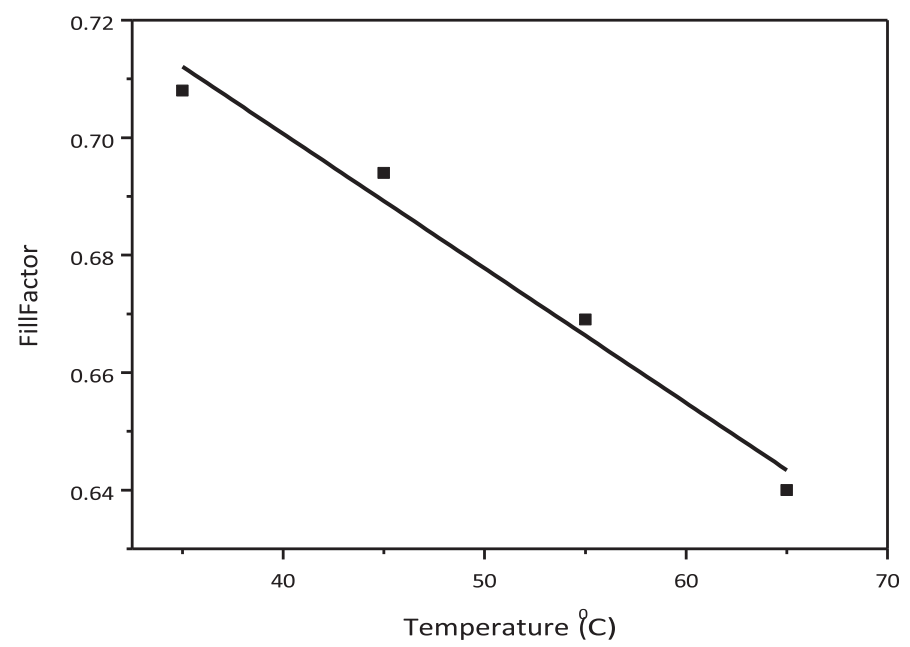

Fig. 6. Variation in fill factor of PV panel with panel surface temperature.

\section{Conclusions}

The performance of PV panel depends on the temperature at which the panel is operating. In this study, the performance analysis of PV panel was evaluated under its varying surface temperature condition. The performance of PV panel was calculated in terms of its electrical parameters, such as $\mathrm{V}_{\mathrm{OC}}, \mathrm{I}_{\mathrm{SC}}, \mathrm{P}_{\mathrm{M}}$ and FF. The results showed that the $\mathrm{P}_{\mathrm{M}}$ and FF of PV panel have a negative linear relation with the panel surface temperature. According to obtained results, the reduction in $\mathrm{V}_{\mathrm{OC}}, \mathrm{P}_{\mathrm{M}}$ and $\mathrm{FF}$ are respectively $12.16 \%, 18.18 \%$ and $9.60 \%$ of the increase in panel surface temperature from $35^{\circ} \mathrm{C}$ to $65^{\circ} \mathrm{C}$ (i.e. $30^{\circ} \mathrm{C}$ increase in panel surface temperature). On the other hand, short circuit current of PV panel experiences very slight increments of $2.7 \%$ with the $30^{\circ} \mathrm{C}$ increase in panel surface temperature. Over and above, this study also demonstrates that the maximum power point (MPP) in the P-V curve moves towards the lower output voltage as the surface temperature of PV panel increases. This movement of MPP disturbs the operation of solar charge controller, which reduces the overall performance of whole PV systems.

\section{Abbreviations}

\begin{tabular}{|l|l|}
\hline$V_{m}$ & Maximum voltage \\
\hline$I_{m}$ & Maximum current \\
\hline$P_{M}$ & Maximum power output \\
\hline$V_{\text {OC }}$ & Open circuit voltage \\
\hline$I_{s C}$ & Short circuit current \\
\hline $\mathrm{PV}$ & Photovoltaic \\
\hline $\mathrm{FF}$ & Fill factor \\
\hline$\Delta \mathrm{V}_{\mathrm{OC}}$ & change in open circuit voltage \\
\hline$\Delta \mathrm{P}_{\mathrm{M}}$ & change in maximum power output of PV panel \\
\hline$\Delta \mathrm{FF}$ & change in fill factor \\
\hline
\end{tabular}




\section{References}

1. Z. Graham and E. Economics., Peak People: The Interrelationship between Population Growth and Energy Resources, Energy Bulletin 20 (2009).

2. B.R. Angel, A.O. Bielsa and A.Martínez-Gracia, Photovoltaics on flat roofs: energy considerations, Energy 36, 4, 1996-2010 (2011).

3. M. Oliver, and T. Jackson, Energy and economic evaluation of building-integrated photovoltaics, Energy 26,4, 431-439 (2001).

4. C.Fernández, J. Francisco and B.R. Ángel, Power supply for pumping systems in northern Chile: photovoltaics as alternative to grid extension and diesel engines, Energy 35,7, 2909-2921 (2010).

5. G. Adolf, C. Hebling and H.W. Schock, Photovoltaic materials, history, status and outlook, Materials Science and Engineering: R: Reports 40,1, 1-46 (2003).

6. P. Bhubaneswari, S. Iniyan and R. Goic, A review of solar photovoltaic technologies, Renewable and sustainable energy reviews 15, 3, 1625-1636 (2011).

7. G. K. Singh, Solar power generation by PV (photovoltaic) technology: A review, Energy 53, 1-13 (2013).

8. El. Chaar and N. El. Zein, Review of photovoltaic technologies, Renewable and sustainable energy reviews 15, 5, 2165-2175 (2011).

9. V. Silvano, G. Acciani and Ottavio Falcone, A finite-element approach to analyze the thermal effect of defects on silicon-based PV cells, IEEE Transactions on Industrial Electronics 59, 10, 3860-3867 (2012).

10. S. Chander, A. Purohit, A. Sharma, S.P. Nehra and M.S. Dhaka, Impact of temperature on performance of series and parallel connected mono-crystalline silicon solar cells, Energy Reports 1, 175-180 (2015).

11. M. A. García and J. L. Balenzategui, Estimation of photovoltaic module yearly temperature and performance based on nominal operation cell temperature calculations, Renewable energy 29, 12, 1997-2010 (2004).

12. M.G. Angee, Study the operating temperature of a PV module, Project Report (2013).

13. A. Virtuani, D. Pavanello, and G. Friesen, Overview of temperature coefficients of different thin film photovoltaic technologies, 5th World Conference on Photovoltaic Energy Conversion. 2010.

14. E. Radziemska, The effect of temperature on the power drop in crystalline silicon solar cells, Renewable Energy 28, 1, 1-12 (2003).

15. H. Bahaidarah, A. Subhan, P. Gandhidasan and S. Rehman, Performance evaluation of a PV (photovoltaic) module by back surface water cooling for hot climatic conditions, Energy 59, 445-453 (2013).

16. K. Stefan, Increased electrical yield via water flow over the front of photovoltaic panels, Solar energy materials and solar cells 82, 1, 131-137 (2004).

17. J.P. Olman, Experimental techniques for engineers, 7th ed, New Delhi, Tata McGraw Hill, 2004. 